\title{
Study on Fracability of Tight Reservoir on the basis of Geophysical Logging: a Case Study of Chang 7 Formation in Longdong Area, Ordos Basin
}

\author{
Zhenhua $\mathrm{Li}^{{ }^{*}}$, Suya Zhang ${ }^{1}$, Lan $\mathbf{Y u}^{1}$, Yuhai Fan ${ }^{2}$ \\ ${ }^{I}$ Energy Engineering Department, Longdong University, Qingyang, Gansu, China \\ ${ }^{2}$ China Aviation Coal Survey Bureau, Xi'an, China \\ *Corresponding Author.
}

\begin{abstract}
Fracability is the ability to form complex fracture to Increase production in tight reservoir under the same fracturing condition. The factors influencing fracturing include reservoir brittleness, fracture toughness, crack system, thermal evolution and mineral content etc. The tight reservoir physical property are poor, and the oil and gas produced under natural conditions is too little, so it is necessary to fracture the reservoir. In this paper, the brittleness and fracture toughness of Chang 7 Formation of Ordos Basin are calculated by logging data under the constraint of laboratory data. In combination with production practice, a new analysis model of reservoir hydraulic fracturing is constructed. The new analysis method is used to evaluate the fracability of Chang 7 stratum in the Ordos Basin, which ranges from $38.7 \%$ to $51.4 \%$. It is basically consistent with the practical fracturing effect of typical wells in this area, which shows that the new method is accurate in calculation, convenient in field application, and can provide experience for the reservoir hydraulic fracturing .
\end{abstract}

Keywords: Fracability, Brittleness, Fracture toughness, Chang 7 Formation, Ordos Basin

\section{Introduction}

At present, unconventional oil and gas resources account for an rising proportion of the global petroleum [1]. It shows that China's unconventional petroleum production in recent years is 66 million tons of oil equivalent, accounting for $20 \%$ of the total petroleum production [2]. Due to the low porosity and permeability, the successful extraction of unconventional oil and gas depends on effective volume fracturing. Therefore, in order to make the reservoir effective fracturing to increase production, it is necessary to analysis the reservoir fracability [3].

As one of the key research contents of unconventional reservoirs, fracability has attracted a lot of scholars' attention. But up to now, the evaluation criteria of fracability are not unified. According to Chong et al., fracability is the property that the stratum can be effectively fractured to form complex cracks and increase production, it is the key parameter of shale gas well evaluation [4]. Breyer et al., think that the brittleness and fracture toughness of reservoir are the two major factors of the fracability [5]. Therefore, the reservoir fracability can be described as the probability of forming complex crack network under the same fracturing technology conditions in order to obtain high economic benefits.

Fracability evaluation methods mainly include experimental method and coefficient evaluation method [6]. The experimental method has low accuracy for the stratum with strong heterogeneity, so it is difficult to conduct in operation and not conducive to field application. Coefficient evaluation method is the most commonly used method for formation fracturing performance by analyzing the weight of each influencing factor [7]. For example, Tang used standardized value and weight coefficient to get the mathematical model of fracturing coefficient [3]; Yuan et al., put forward the evaluation method of fracability with rock mechanics parameters as independent variables and fracturing index as dependent variables [8]; Zhao et al., established a fracturing model integrating the characteristics of reservoir brittleness, fracture toughness and natural weak surface [6]. However, due to too many

ISSN: 0010-8189

(C) CONVERTER 2020

Www.converter-magazine.info 
influencing factors, the existing coefficient method evaluation models have some defects. Some of them only considered a single factor so the reservoir fracability evaluated is not accurate, and in others the factors considered are too complex to be used. Therefore, a comprehensive, accurate and simple reservoir fracability evaluation model is urgently needed.

Based on the regional geological data and logging data, the author carried out the evaluation research on the brittleness and fracture toughness, established the evaluation model of reservoir fracability of Chang 7 Formation, Ordos Basin, and put it into application.

\section{Geological Setting}

Ordos Basin is a large petroliferous basin formed since Permian, which is rich in various mineral resources. Longdong area is in the southwest of the Basin, it is area of about $5 \times 10^{4} \mathrm{~km}^{2}$ (Fig. 1). Chang 7 Formation is the peak period of lake basin development, and its sedimentary facies is mainly lacustrine facies, alternating delta front and delta Bay. Lacustrine sediments formed a thick layer of good source rocks, which provided necessary conditions for the formation of shale gas in study area [9]. The top structure of Chang 7 Formation in Longdong area is a large gentle monocline with NW tendency, with gentle structural amplitude and small dip angle.

The lithology of Chang 7 Formation in Longdong area is mainly black shale, dark gray siltstone, containing a large number of plant fossils (Fig. 2). The mineral composition of shale and fine sandstone in Chang 7 formation was tested. The results show that the main brittle minerals are quartz and pyrite, and the contents are $19 \%-42 \%$ and $1 \%$ - 4\%, respectively, with an average of $36 \%$ and $2 \%$. The contents of non brittle minerals are mainly feldspar, clay and carbonate, which are $18 \%-42 \%, 21 \%-36 \%$ and $4 \%-6 \%$ respectively, with an average of $26 \%, 32 \%$ and $4 \%$. 

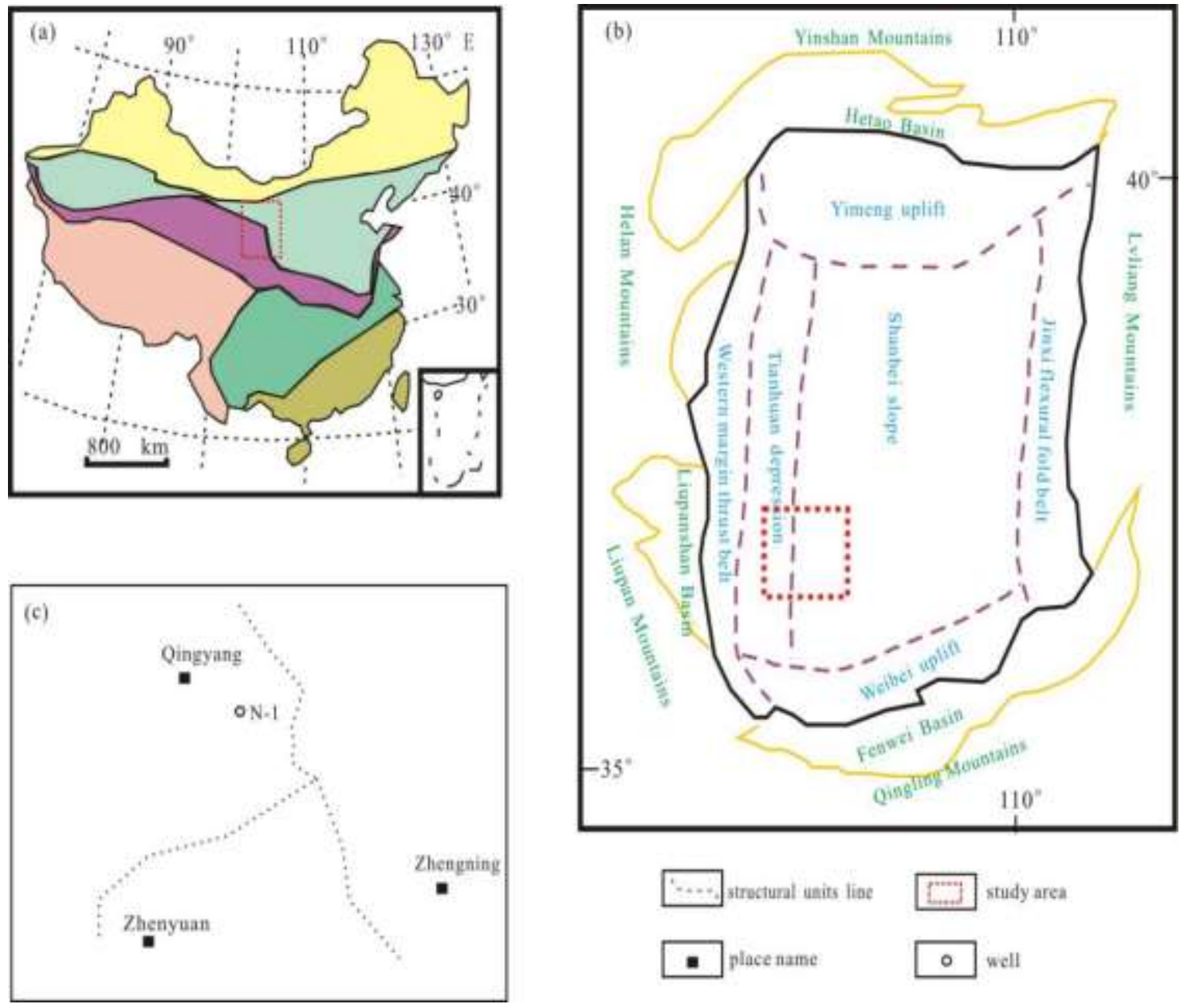

Fig 1: Structural map of Longdong area in Ordos Basin.

(a) China Structural map. (b) Structural of Ordos Basin. (c) Well location.
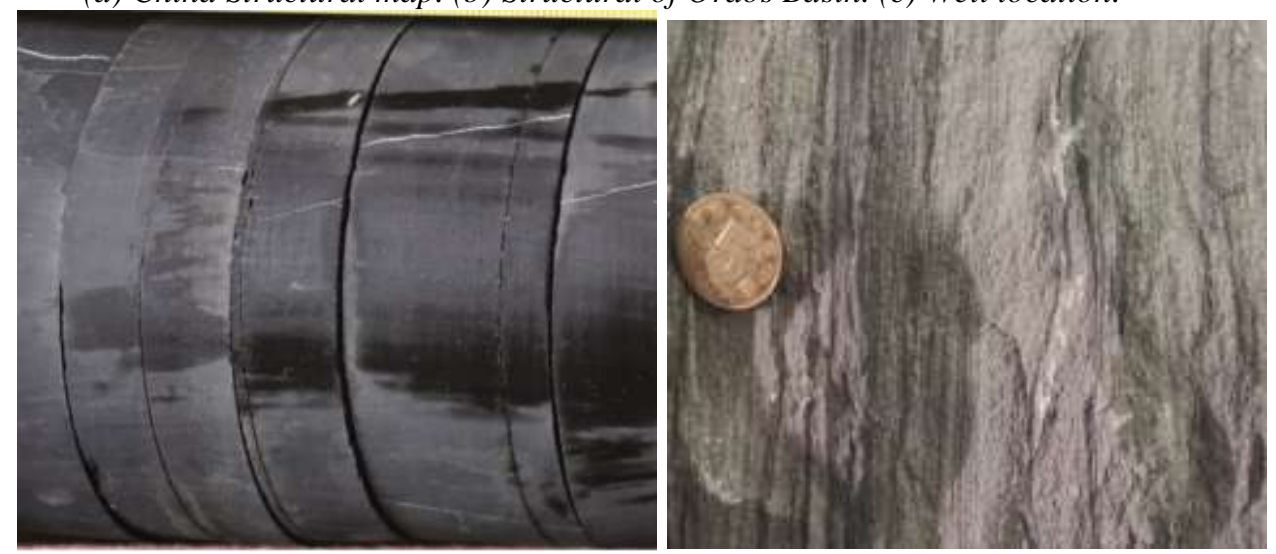

Fig 2: Core photos of Chang 7 Formation in study area.

\section{Fracability Evaluation}

The fracability of reservoir is affected by many geological factors, such as rock brittleness, fracture toughness, natural fractures and diagenesis. In addition, crustal stress, sedimentary environment also affect it.

\subsection{Rock Brittleness}

ISSN: 0010-8189

(C) CONVERTER 2020

Www.converter-magazine.info 
Brittleness is a property that indicates the rock has no obvious shape change under the action of external force until failure. Reservoir brittleness is the primary factor of hydraulic fracturing. Morley et al., propose that brittleness is the lack of plasticity [10]; Ramsey thinks that rock brittle failure occurs when the cohesion is destroyed [11]; Obert et al., consider that the property of failure which reaches or slightly exceeds the yield strength is brittleness [12]. The brittleness of reservoir can be characterized by brittleness index. In petroleum geology, the brittleness index reflects the difficulty of reservoir hydraulic fracturing. The stratum with high brittleness index is easy to form complex network fractures after fracturing. Scholars have done lots of research in unconventional reservoir brittleness, and proposed a variety of quantitative calculation methods of brittleness index. However, there are two most commonly used methods. One is the mineral composition method based on X-ray diffraction data, and the other is the rock mechanics parameter method.

\subsubsection{Mineral Component Evaluation Method}

Quartz, pyrite and dolomite are the main brittle minerals in rocks, and their contents determine the brittleness of reservoirs. Rock brittleness index could be quantitatively evaluated through analyzing the characteristics of rock mineral composition [13]. The brittleness index can be calculated by equation (1).

$$
B=\sum_{i=1}^{m} a_{i} M_{i} \quad a_{i}=E_{i} / \mu_{i}
$$

Where $\mathrm{B}$ is brittleness index of rock, $\% ; \mathrm{a}_{\mathrm{i}}$ is brittleness coefficient of various minerals relative to quartz; $\mathrm{i}$ is mineral species; $\mathrm{M}$ is volume content of minerals in the stratum, $\% ; \mu_{\mathrm{i}}$ and $\mathrm{E}_{\mathrm{i}}$ are Poisson's ratio and elastic modulus of the $i_{\text {th }}$ mineral, respectively.

\subsubsection{Mechanics Parameter Method}

Both Poisson's ratio and elastic modulus can reflect brittleness of rock. Generally speaking, the larger the elastic modulus is, the larger the brittleness index is; the larger the Poisson's ratio is, the smaller the brittleness index is (Fig. 3, Fig. 4). Therefore, rock brittleness can be characterized by positive normalized elastic modulus as equation (2) and inverse normalized Poisson's ratio as equation (3). Brittleness index is affected by the Poisson's ratio and elastic modulus, Rickman proposes to calculate the brittleness index by taking half of the normalized Poisson's ratio and elastic modulus [14]. The equation is as follows (4):

$$
\begin{array}{r}
\Delta E=\frac{E-E_{\min }}{E_{\max }-E_{\min }} \times 100 \% \\
\Delta \mu=\frac{\mu_{\max }-\mu}{\mu_{\max }-\mu_{\min }} \times 100 \% \\
B=\frac{\Delta E+\Delta \mu}{2} \times 100 \%
\end{array}
$$

Where $\mathrm{E}$ and $\Delta \mathrm{E}$ refer to the average elastic modulus and the normalized elastic modulus of stratum; $\mu$ and $\Delta \mu$ are the average Poisson's ratio and normalized Poisson's ratio of stratum, respectively; Brittleness index is represented by $\mathrm{B}$; the subscript min is minimum value of the parameter, while subscript max represents the maximum value in a certain strata. 


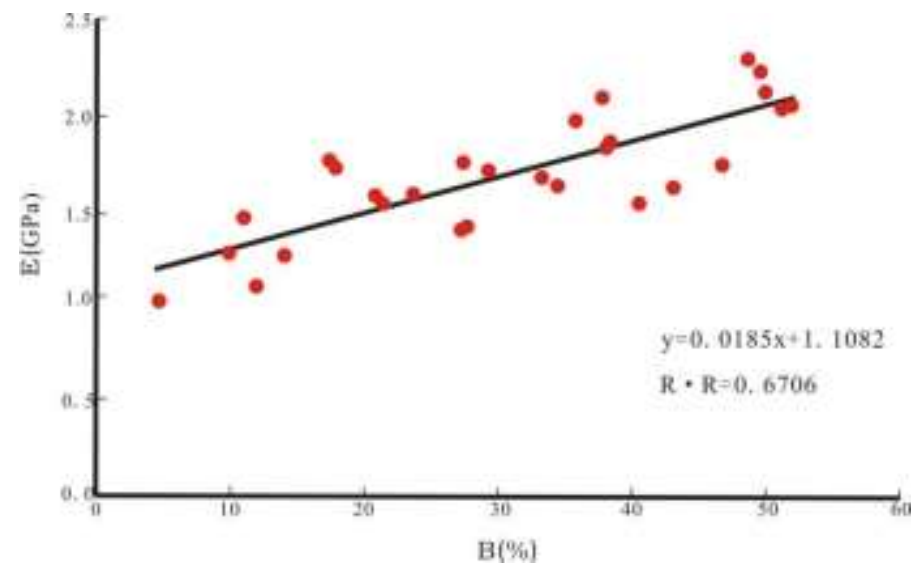

Fig 3: Diagram of brittle index and elastic modulus.

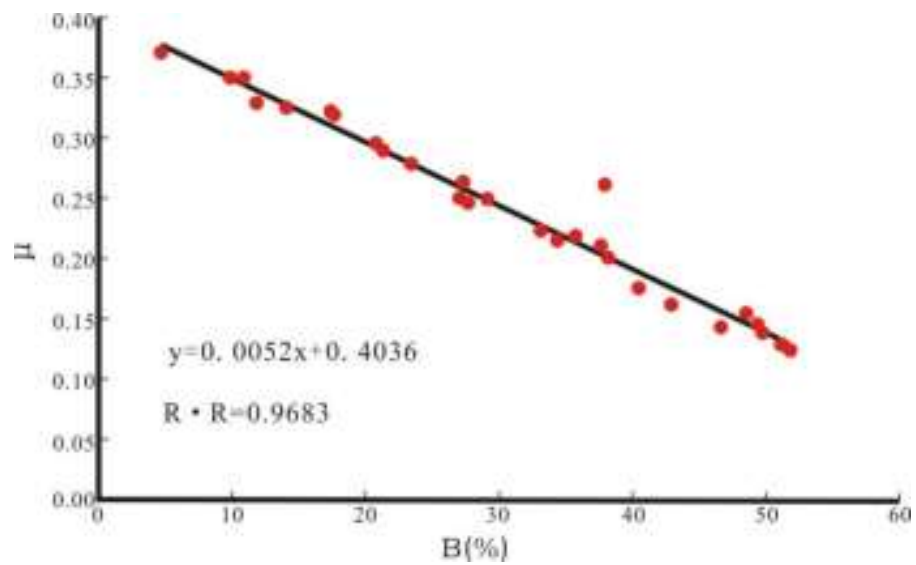

Fig 4: Diagram of brittle index and Poisson's ratio.

The mechanical parameters measured in laboratories are accurate and reliable, but they are unrealistic to take out the whole well section core for testing, and the testing cost is high, so only a small number of samples with specified depth are measured for parameter calibration. When the logging data are complete, including the time difference of longitudinal and transverse acoustic waves measured by density and acoustic logging data, the dynamic mechanical parameters of the whole stratum target section can be calculated by equation (5) and equation (6). Taking the relationship between dynamic and static mechanical parameters into consideration, the dynamic parameters of the whole layer can be transformed into static parameters, and through equation (4) the brittleness index could be calculated. The results calculated by logging method have high accuracy and can continuously reflect rock mechanics state, so it is the most reliable brittle index calculation method at present [15].

$$
\begin{aligned}
E_{d} & =\frac{\rho}{\Delta t_{S}{ }^{2}} \frac{3 \Delta t_{s}{ }^{2}-4 \Delta t_{p}{ }^{2}}{\Delta t_{s}{ }^{2}-\Delta t_{p}{ }^{2}} \times 10^{6} \\
\mu_{d} & =\frac{\Delta t_{s}{ }^{2}-2 \Delta t_{p}{ }^{2}}{2\left(\Delta t_{s}{ }^{2}-\Delta t_{p}{ }^{2}\right)}
\end{aligned}
$$

Where $E_{d}$ represents dynamic elastic modulus, while $\mu_{\mathrm{d}}$ represents dynamic Poisson's ratio of rock; $\rho$ refers to density of the stratum, $\mathrm{g} / \mathrm{cm}^{3}$; longitudinal wave time difference is represented by $\Delta \mathrm{T}_{\mathrm{P}}$, while $\Delta \mathrm{T}_{\mathrm{S}}$ represents shear wave time difference, $\mu \mathrm{s} / \mathrm{m} ; 10^{6}$ is the coefficient converting elastic modulus $\mathrm{Pa}$ to GPa.

\subsubsection{Brittleness Index of Chang 7 Formation}

Triaxial compression test was carried out on silt-stone and fine sandstone core samples in Longdong area, the rock sample specification was $\Phi 38.1 \mathrm{~mm} \times 2 \mathrm{~mm}$. In addition to geophysical logging data, we obtained the data results in Table 1. The minimum and maximum values of $\mathrm{E}_{\mathrm{s}}$ and $\mu_{\mathrm{s}}$ in silt-stone sample are 2.213 and $2.553 \mathrm{GPa}, 0.182$ and 0.239 , and the corresponding brittleness index is $44.9 \%$. The minimum and maximum values of $\mathrm{E}_{\mathrm{s}}$ and $\mu_{\mathrm{s}}$ in fine sandstone sample are 2.323 and $2.475 \mathrm{GPa}, 0.192$ and 0.221 , and the corresponding brittleness index is $47.9 \%$.

ISSN: 0010-8189 
Meanwhile, the brittleness index by mineral composition method (equation 1) is $52.5 \%$. Combined with logging data, we obtained the brittleness index profile of Chang 7 Formation in the study area (Fig. 5). The range of brittleness indexs is from $44.9 \%$ to $52.5 \%$, which is favorable for reservoir fracturing.

Table 1: Mechanics parameter data of X-1 and X-2 rock samples.

\begin{tabular}{|c|c|c|c|c|c|c|}
\hline Sample & Lithology & Depth (m) & $\mathrm{E}_{\mathrm{s}}(\mathrm{GPa})$ & $\mu_{\mathrm{s}}$ & $\mathrm{Ed}(\mathrm{GPa})$ & $\mu_{\mathrm{d}}$ \\
\hline \multirow{9}{*}{$X-1$} & \multirow{9}{*}{ Silt-stone } & \multirow{9}{*}{$\begin{array}{c}1758.1- \\
1758.9\end{array}$} & 2.303 & 0.182 & 2.767 & 0.22 \\
\hline & & & 2.451 & 0.189 & 2.768 & 0.22 \\
\hline & & & 2.213 & 0.195 & 2.659 & 0.22 \\
\hline & & & 2.385 & 0.182 & 2.832 & 0.23 \\
\hline & & & 2.384 & 0.239 & 2.916 & 0.22 \\
\hline & & & 2.493 & 0.196 & 2.865 & 0.26 \\
\hline & & & 2.519 & 0.188 & 3.063 & 0.22 \\
\hline & & & 2.457 & 0.213 & 3.557 & 0.29 \\
\hline & & & 2.553 & 0.237 & 3.209 & 0.25 \\
\hline \multirow{6}{*}{$\mathrm{X} 2$} & \multirow{6}{*}{ Fine sandstone } & \multirow{6}{*}{$\begin{array}{c}1489.6- \\
1494.3\end{array}$} & 2.336 & 0.221 & 2.404 & 0.23 \\
\hline & & & 2.323 & 0.213 & 2.532 & 0.14 \\
\hline & & & 2.475 & 0.213 & 2.852 & 0.22 \\
\hline & & & 2.427 & 0.192 & 2.769 & 0.21 \\
\hline & & & 2.415 & 0.197 & 2.733 & 0.22 \\
\hline & & & 2.443 & 0.214 & 2.726 & 0.22 \\
\hline
\end{tabular}

\begin{tabular}{|c|c|c|c|c|c|c|c|c|}
\hline \multirow{2}{*}{ Stratum } & $\begin{array}{c}\mathrm{SP}(\mathrm{MV}) \\
-100-100\end{array}$ & $\begin{array}{l}\mathrm{DEN}(\mathrm{g} / \mathrm{cm}) \\
1-3\end{array}$ & \multirow{2}{*}{$\begin{array}{l}\text { Depth } \\
\text { (m) }\end{array}$} & \multirow{2}{*}{ Litbolog } & $\begin{array}{c}\text { Calculate AC } \\
150-600 \\
\end{array}$ & $0.1 \stackrel{\mu,}{-} 0.4$ & $0-\mathrm{E}_{\mathrm{d}} 100$ & $0 \stackrel{B I_{n e}(\%)}{-100}$ \\
\hline & $\begin{array}{c}\text { GR(API) } \\
0-300\end{array}$ & $\begin{array}{l}\text { well diameter } \\
15-45\end{array}$ & & & $\begin{array}{r}\mathrm{AC}(\mu \mathrm{s} / \mathrm{m}) \\
300-100\end{array}$ & $0.1 \stackrel{\mu_{t}}{-} 0.4$ & $0 \stackrel{\text { Es }}{-} 100$ & $0-\mathrm{BI}_{-}(\mathrm{\%} \%)$ \\
\hline Chang 7 & - & $P \leq$ & $1470=$ & \begin{tabular}{|l|l} 
& \\
& \\
& \\
& \\
& \\
& \\
11 \\
\end{tabular} & $\sum_{5} \sum_{3}^{3}$ & 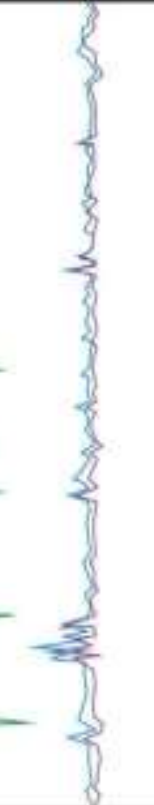 & $\sum_{3}^{3}$ & 6 \\
\hline
\end{tabular}

Fig 5: Chang 7 brittle profile interpreted by geophysical logging.

3.2 Fracture toughness

ISSN: 0010-8189 
The fracture toughness is the ability of stratum to prevent crack extension. It is an inherent characteristic of rock and has nothing to do with the size, shape and applied stress of crack itself. The fracture toughness of rock could be divided into opening, staggering and tearing (type I, type II and type III). The fracture toughness of type I and type II are common in hydraulic fracturing, but type III fractures are relatively rare. The results show that one important reason for rock failure is the forward propagation of micro cracks, and the main reason for the forward propagation is that micro cracks are subjected to tensile stress.

Fracture toughness can be obtained by Brazilian disk experiment in laboratory and by logging data calculation. based on lots of experimental data, Jin et al., put forward the common equation for calculating fracture toughness [16], and the equation are (7), (8).

$$
\begin{aligned}
& K_{\mathrm{Ic}}=0.2176 \sigma_{n}+0.0059 S_{t}^{3}+0.0923 S_{t}^{2}+0.517 S_{t}-0.3322 \\
& K_{I I C}=0.0956 \sigma_{n}+0.1383 S_{t}-0.082
\end{aligned}
$$

Where $\mathrm{K}_{\mathrm{Ic}}$ and $\mathrm{K}_{\mathrm{IIc}}$ refer to the fracture toughness of type I and type II, MPa.m ${ }^{0.5}$; $\sigma_{\mathrm{n}}$ and $\mathrm{S}_{\mathrm{t}}$ represent confining pressure and tensile strength of the stratum, MPa.

The greater the fracture toughness of rock, the more difficult it is to maintain the fracture, and the smaller the fracability of the stratum. The stratum fracture toughness index $\mathrm{Kn}$ is half of the type I and the type II fracture toughness index [17], and the equation is as follows:

$$
K_{n}=0.5 \frac{K_{I C \max }-K_{I C}}{K_{I C \max }-K_{I C \min }} \times 100 \%+0.5 \frac{K_{I I C \max }-K_{I I C}}{K_{I I C \max }-K_{I I C \min }} \times 100 \%
$$

Where $\mathrm{K}_{\mathrm{ICmax}}, \mathrm{K}_{\mathrm{ICmin}}$ and $\mathrm{K}_{\mathrm{IICmax}}, \mathrm{K}_{\mathrm{IICmin}}$ refer to the maximum and minimum values of type I, type II fracture toughness, respectively. Tensile strength and confining pressure of the stratum could be obtained by empirical equation (10), (11), (12) and (13):

$$
\begin{aligned}
I_{G R} & =\frac{G R-G R_{\min }}{G R_{\max }-G R_{\min }} \\
V_{s h} & =\frac{2^{G_{c u r} \times I_{s h}}-1}{2^{G c u r}-1} \\
\sigma_{n} & =E_{d}\left[0.008 V_{s h}+0.045\left(1-V_{s h}\right)\right]
\end{aligned}
$$

Where: $\mathrm{I}_{\mathrm{GR}}$ represents the mud content index, dimensionless; $\mathrm{GR}_{\max }, \mathrm{GR}_{\min }$ represent the maximum , minimum values of gamma value, API; $\mathrm{V}_{\mathrm{SH}}$ and $\mathrm{G}_{\mathrm{cur}}$ are the mud content and Hilchie index, respectively; As for the old reservoir, 2 is taken; $\mathrm{E}_{\mathrm{d}}$ is the dynamic elastic modulus, MPa.

According to the existing logging data and experimental data (Table 2, Fig. 6) in the study area, the fracture toughness index of X-1 and X-2 samples in Longdong area is calculated using the above equations, which ranges from $24.3 \%$ to $45.8 \%$.

Table 2: Fracture toughness data of rock samples.

\begin{tabular}{ccccc}
\hline \multirow{2}{*}{ Sample } & \multicolumn{2}{c}{ Specimen size $(\mathrm{mm})$} & $\begin{array}{c}\text { Maximum failure load } \\
\left(\mathrm{K}_{\mathrm{N}}\right)\end{array}$ & $\begin{array}{c}\text { Fracture toughness } \\
\mathrm{Kn}(\mathrm{MPa} \cdot \sqrt{\mathrm{m}})\end{array}$ \\
\hline X1 & 36.42 & 19.54 & 1.540 & 0.467 \\
$\mathrm{X} 1$ & 37.23 & 19.23 & 2.660 & 0.736 \\
$\mathrm{X} 1$ & 35.63 & 19.06 & 2.360 & 0.639 \\
X2 & 36.12 & 17.68 & 1.870 & 0.600 \\
$\mathrm{X} 2$ & 36.16 & 17.13 & 1.510 & 0.298 \\
\hline
\end{tabular}

ISSN: 0010-8189 


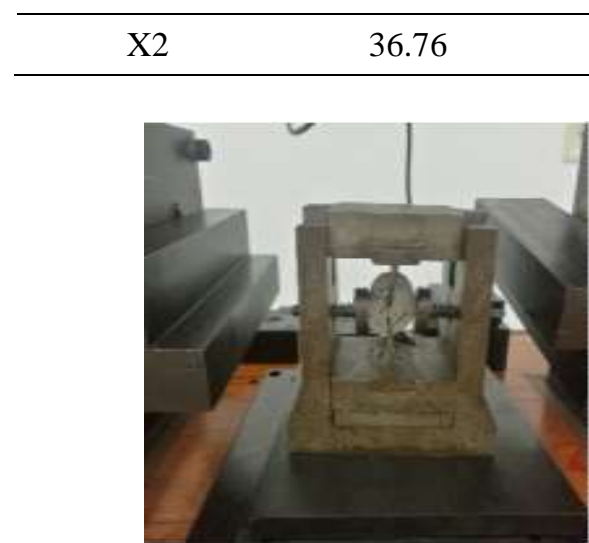

DL-1

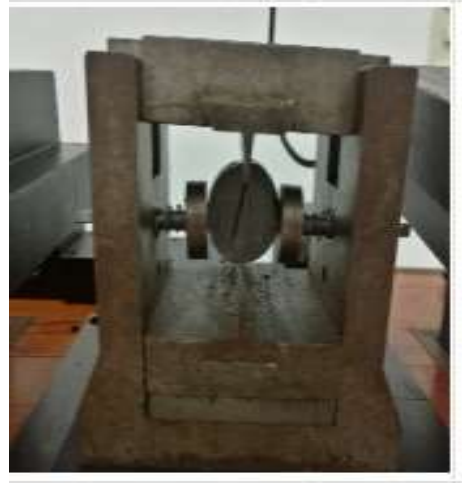

DL-4
18.29

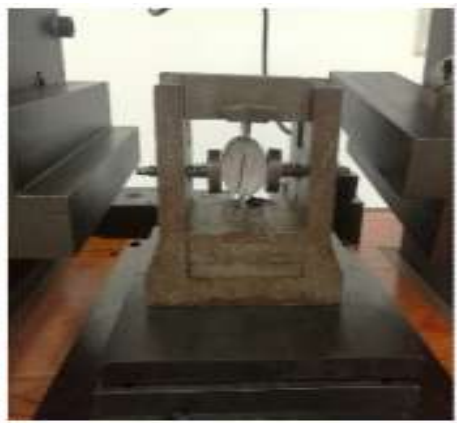

$\mathrm{DL}-2$

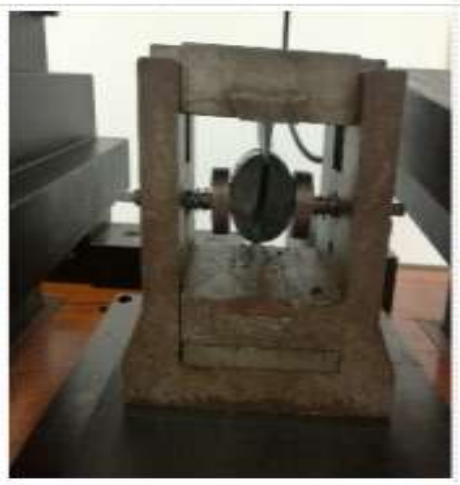

DL-5

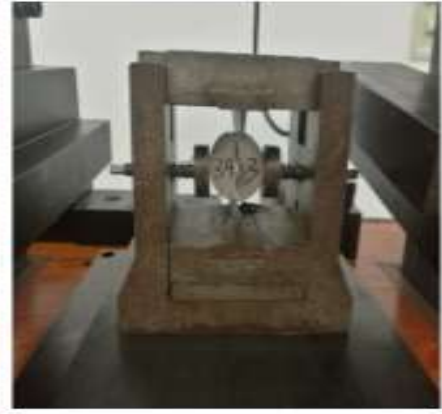

DL-3

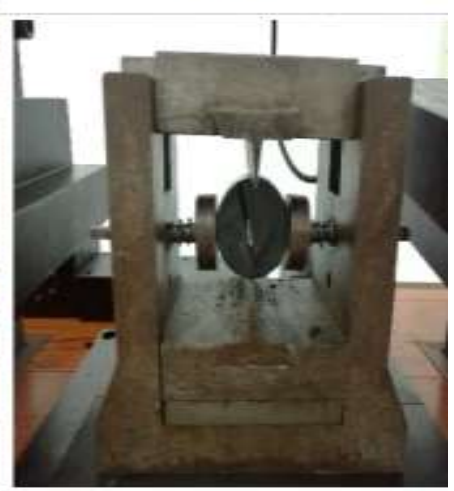

DL-6

Fig 6: Fracture toughness test diagram of rock samples.

\subsection{Fracability evaluation model}

Previous scholars have done many work on reservoir fracturing. Some scholars proposed to use only brittleness index to measure the fracturing performance. Others proposed to use brittleness index, fracture toughness and natural weak surface to evaluate the fracturing performance, such as the product method proposed by Yuan and the parameter weight method proposed by Tang. Some of the the above evaluation methods only consider the main role of brittleness and ignore other factors, while others are too complicated and difficult to put into practice because of too many factors considered. In this paper, the reservoir fracability evaluation model in Longdong area is established, which is (13):

$$
\operatorname{Ffrc}=(1-\omega) B+\omega K n
$$

Where: $\omega$ is the weight coefficient of fracture toughness parameter of reservoir, which varies from 0.5 to 0.2 , dimensionless. In study area $\omega=0.3$, and then there would be the equation (14):

$$
\text { Ffrc }=0.7 \mathrm{~B}+0.3 \mathrm{Kn}
$$

\section{Case Application}

According to the experimental and geophysical logging data, we obtain the fracability profile of well $\mathrm{N}-1$ in Longdong area as Figure 7. It shows that the strata with higher brittleness generally have higher fracability, but not always the case because the points with higher brittleness index may also have higher fracture toughness (lower fracture toughness index), and the fracability is affected by both the brittleness and fracture toughness.

Generally speaking, if the fracability index is greater than 0.4 , the strata has good fracability. The fracability index of N-1 wells in Longdong area calculated using above method ranges from $38.7 \%$ to $51.4 \%$, which shows the ISSN: 0010-8189 
overall fracability is high. The evaluation results are completely consistent with practical fracturing effect. It shows that the new method is accurate and could provide experience for the reservoir hydraulic fracturing.

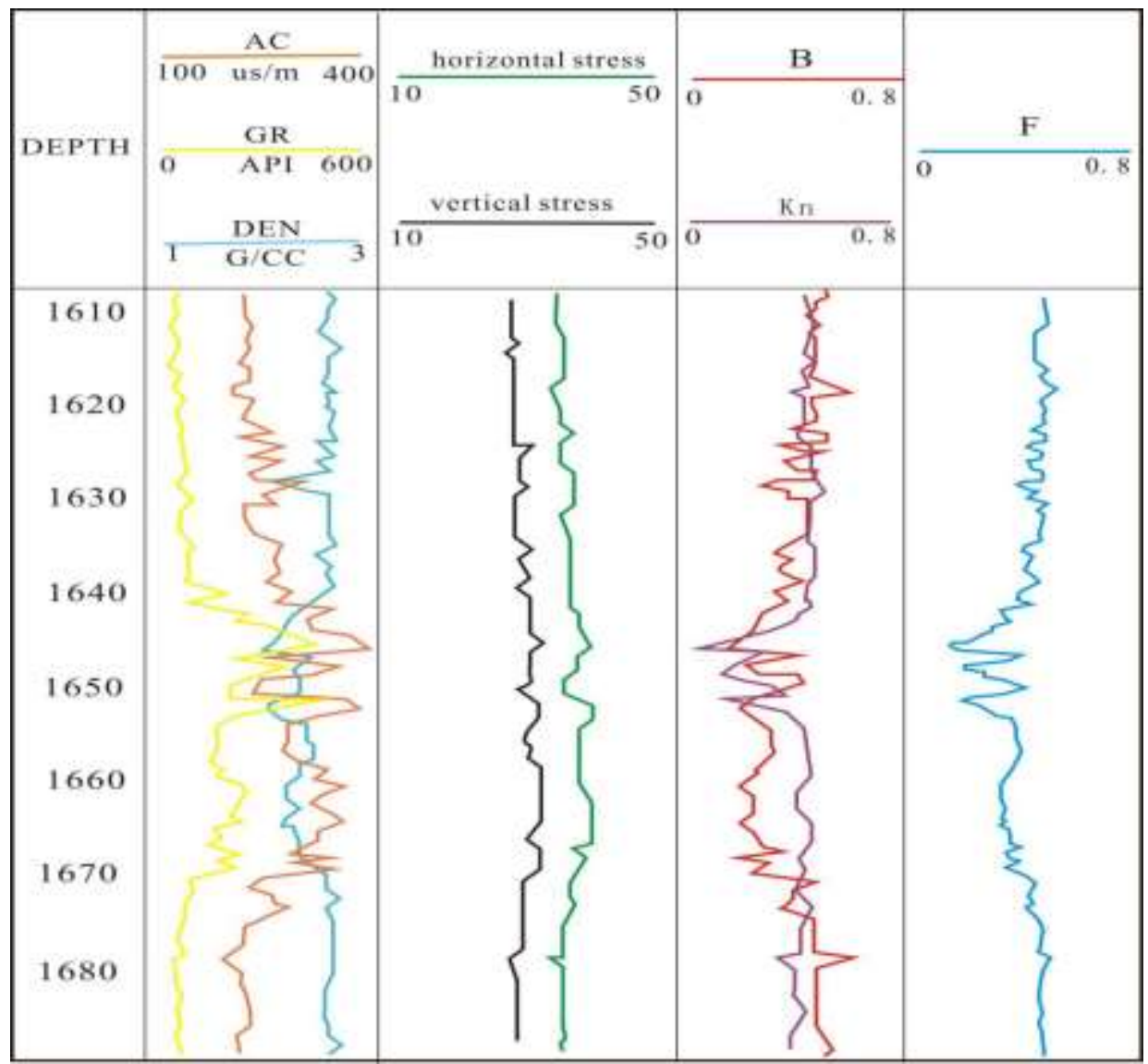

Figure 7: Fracability profile of well $N$-1 in study area

\section{Conclusion}

(1) The elastic modulus and Poisson's ratio in study area are 2.213-2.553GPa and 0.181-0.237, respectively; the brittleness index ranges from $44.9 \%$ to $52.5 \%$, the fracture toughness index ranges from $24.3 \%$ to $45.8 \%$, and the fracability index ranges from $38.7 \%$ to $51.4 \%$.

(2) Brittleness is the primary factor in reservoir fracability evaluation, which often represents the fracturing ability, but it is not accurate to take brittleness as the only evaluation standard of fracturing ability. Therefore, a new evaluation model of reservoir fracability is established on the basis of brittleness and fracture toughness.

(3) The model is applied to N-1 well and the results are completely consistent with practical fracturing effect, which reflects the correctness of the model. It shows that the stratum with high brittleness, low fracture toughness should be selected as a "sweet spot zone".

\section{Acknowledgements}

This research was supported by Youth Science and Technology Foundation of Gansu Province (Grant No.20JR10RA139).

\section{References}

ISSN: 0010-8189 
[1] Z. Zou, G. Yang, G. Zhang et al., "Conventional and unconventional petroleum orderly accumulation: Concept and practical significance," Petroleum Exploration and Development, vol.41, no.2, pp.14-27, 2014.

[2] C.Z. Jia, M. Zheng, Y.F. Zhang, "Unconventional hydrocarbon resources in China and the prospect of exploration and development," Petroleum Exploration and Development (in Chinese), vol.39, no.2, pp.129-136, 2012.

[3] Y. Tang , Y. Xing, L. Li et al., "Influence factors and evaluation methods of the gas shale fracability," Earth Science Frontiers, vol.19, no.5, pp.356-363, 2012.

[4] K.K. Chong, W.J. Grieser, Aripatke O.A, et al., "A Completions guide book to shale play development: a review of successful approaches toward shale-play stimulation in the last two decades," SPE International Oil and Gas Conference and Exhibition, 2010.

[5] J.A. Breyer, H. Alsleben, M.B. Enderlin, "Predicting fracability in shale reservoirs,", 2012.

[6] J. Zhao, W. Xu, "A new method for fracability evaluation of shale gas reservoirs," Natural gas geoscience, pp.1672-1926, 2015.

[7] Z. Fan, C. Lin, T. Wang et al., "Logging optimization on brittle index of tight formation rocks," Acta Peotrolei Sinica, vol.36, no.11, pp.1411-1420, 2015.

[8] J. Yuan, J. Deng, D. Zhang et al., "Fracability evaluation of shale-gas reservoirs," Acta Petrolei Sinica, vol.34, no.3, pp.523-527, 2014.

[9] H. Yang, W. Dou, X. Liu, et al., "Sedimentary facies analysis of Yanchang group 7, Triassic System in Ordos Basin,” Journal of sedimentary Sciences, vol.31, no.2, pp. 254-263, 2010.

[10] A. Morley, "Strength of materials," London: Longman Green, pp.71-72, 1944.

[11] J. G Ramsay, "Folding and fracturing of rocks," London: McGraw-Hill, pp.44-47, 1967.

[12] L. Obert, W.I. Duvall, "Rock mechanics and the design of structures in rock," New York; John Wiley, pp.78-82, 1967.

[13] H.Y. Diao, "Rock mechanical properties and brittleness evaluation of shale reservoir,"Acta Petrologica Sinica, vol.9, no.9, pp. 3300-3306, 2013.

[14] R. Rickman, M. Mullen, J. Petreet al., "A practical use of shale petrophysics for stimulation design optimization: All shale plays are not clones of the Barnett Shale," SPE Annual Technical Conference and Exhibition. Denver, Colorado, USA: SPE, vol.10, pp.1-11, 2008.

[15] Z.H. Li, K. Gai, Z.J. Chen, et al, "Brittleness logging evaluation of Shihezi formation in Yanchang Gas field in Ordos Basin based on rock mechanical characteristics,"E3S Web of Conferences, 2019.

[16] J. Yan, C. Mian, "Determination of fracture toughness for deep well rock geophysical logging data," Chinese Journal of Rock Mechanics and Engineering, vol. 20, no. 4, pp. 454-456, 2001.

[17] Y. Jin, J. Yuan, M. Chen, et al., "Determination of rock fracture toughness $\mathrm{K}_{\text {IIC }}$ and its relationship with tensile strength," Rock Mechanics and Rock Engineering, vol. 44, no. 5, pp. 621-627, 2011. 